\title{
LITERASI PRODUK BERSERTIFIKASI HALAL DALAM RANGKA MENINGKATKAN PENJUALAN PADA UMKM
}

\author{
${ }^{1}$ Siti Indah Purwaning Yuwana, ${ }^{2}$ Hikmatul Hasanah \\ 1,2UIN Kiai Haji Achmad Siddiq, Jember, Indonesia \\ IndahYuwana@uinkhas.ac.id
}

(Diterima: 12 November 2021; Direvisi: 14 November 2021; Dipublikasikan: November 2021)

\begin{abstract}
ABSTRAK
Banyaknya produk lokal hasil dari UMKM di Jember beredar tanpa labelisasi halal menjadikan penulis terdorong untuk melakukan pengabdian masyarakat tentang literasi produk sertifikasi halal. Beberapa pelaku UMKM sudah melakukan perubahan dengan mengurus proses sertifikasi halal untuk produknya, sehingga mampu menambah kepercayaan masyarakat untuk melakukan pembelian, yang berdampak pada peningkatan omset penjualan produk. Namun, jumlah pelaku usaha yang melaksanakan sertifikasi tersebut, tidak sebanding dengan banyaknya produk hasil UMKM yang beredar tanpa sertifikasi halal. Tulisan ini menguraikan program pendampingan literasi yang dilakukan oleh penulis dalam fungsinya untuk memberikan pemahaman dan pengetahuan berkaitan dengan sertifikasi halal pada beberapa UMKM di Kecamatan Sumbersari, Kabupaten Jember. Program pengabdian kami melalui workshop literasi yang dilakukan dua sesi yaitu sesi pertama memberikan paparan teoritis tentang pengertian produk halal dan sertifikasi halal, kemudian sesi selanjutnya memberikan tahapan proses pengurusan sertifikasi produk halal dan contoh pelaku UMKM yang sudah melaksanakannya. Hasil dari program pengabdian masyarakat ini memberikan dampak positif kepada pelaku UMKM, yaitu pemahaman arti penting pengurusan sertifikasi halal dan pengaruhnya terhadap volume penjualan. Selain itu, pelaku UMKM juga menjadi paham bagaimana tahapan pengurusan sertifikasi produk halal.
\end{abstract}

Kata Kunci : Produk ; Halal ; Sertifikasi ; UMKM

\section{ABSTRACT:}

Many local products produced by SMEs in Jember circulating without halal labeling makes the authors compelled to do community service about literacy of halal certification products. Some MSME actors have made changes by managing the halal certification process for their products, so as to increase public confidence in making purchases, which has an impact on increasing product sales turnover. However, the number of business actors who carry out the certification is not comparable to the number of products produced by MSMEs circulating without halal certification. This paper describes the literacy assistance program carried out by the author in its function to provide understanding and knowledge related to halal certification in several MSMEs in Sumbersari District, Jember Regency. Our service program through literacy workshops carried out in two sessions, namely the first session providing theoretical exposure about the meaning of halal products and halal certification, then the next session providing stages of the process of obtaining halal product certification and examples of MSME actors who have implemented it. The results of this community service program have a positive impact on MSME actors, namely understanding the importance of obtaining halal certification and its effect on sales volume. In addition, MSME actors also understand how the stages of managing halal product certification are.

Keywords : Product; Halal; Certification; MSME

\section{PENDAHULUAN}

Jumlah penduduk di Indonesia yang besar, mayoritas beragama Islam. Tentu saja akan membentuk mindset masyarakat Indonesia dengan beranggapan pentingnya sebuah label halal sebagai bahan pertimbangan untuk sebuah keputusan pembelian. Halal menjadi faktor 
penting yang harus di perhitungkan dalam pemilihan suatu produk, seperti makanan dan kosmetik. Realitas umat Islam mengatakan bahwa halal merupakan bagian dari sistem kepercayaan, moralitas dan integral dalam aktifitas kehidupan sehari-hari. Respon positif umat Islam dengan kehadiran produk halal yang berkaitan dengan keputusan pembelian. Produk halal harus diakui sebagai simbol kebersihan, keamanan, dan kualitas tinggi bagi konsumen Muslim (Al Farisi, 2020).

Literasi halal merupakan pengetahuan dan pemahaman seseorang atau masyarakat tentang suatu produk yang akan mereka konsumsi. Suatu produk halal atau haram tidak hanya terbatas pada label halal saja, akan tetapi masyarakat juga harus memahami dan mengetahui barang yang dikonsumsinya tersebut dari bahan halal atau tidak. Literasi halal mengajarkan tentang membedakan produk barang dan jasa yang halal atau haram sehingga menjadikan pemahaman yang lebih baik mengenai hukum Islam atau syariah (Salehudin \& Mukhlish, 2012).

Sebagaimana kita ketahui bahwa tingkat literasi masyarakat masih rendah mengenai hukum halal. Mereka mengetahui halal atau haramnya suatu produk hanyalah dari kemasan yang terdapat label halalnya saja. Apalagi pada jaman sekarang ini begitu menjamur produk yang tidak menggunakan label halal. Melihat kondisi tersebut, beberapa pelaku UMKM yang melakukan perubahan dengan mengurus proses sertifikasi halal untuk produknya, sehingga menambah kepercayaan masyarakat untuk melakukan pembelian, yang tentu saja berpengaruh terhadap omset penjualan produk. Namun, di sisi lain, masih banyak pelaku UMKM di Jember yang belum sadar akan pentingnya pengurusan sertifikasi halal tersebut.

Uraian analisis situasi di atas menjadi dasar pengetahuan bahwa berbagai realita produk makanan dan kosmetik ternyata masih banyak yang belum memiliki sertifikasi halal (Farhan, 2018). Pelaku UMKM di Kecamatan Sumbersari masih banyak yang kurang peduli bahwa produk makanan dan kosmetik yang dijual oleh mereka perlu mendapatkan jaminan halalnya karena makanan dan kosmetik tersebut akan dikonsumsi oleh masyarakat luas.

Bermula dari latar belakang fenomena di lapangan tersebut, maka perlu peningkatan literasi atau pemahaman mengenai halal terhadap suatu produk yang akan dikonsumsi bagi masyarakat, khususnya pelaku UMKM produk makanan dan kosmetik di Jember, sehingga mampu menjawab tantangan perkembangan jaman tentang sertifikasi halal yang akan mempengaruhi nilai penjualan produk usahanya. Tujuan penelitian pengabdian ini untuk menganalisis literasi serta religiusitas pelaku UMKM terhadap produk makanan dan kosmetiknya, sehingga nanti mampu memberikan gambaran bahwa akan berpengaruh secara simultan terhadap keputusan pembelian masyarakat dan omset penjualan produknya.

Adapun masalah yang menjadi tujuan untuk dicapai dalam program pengabdian kepada masyarakat ini adalah : Bagaimana pelaku UMKM di Kecamatan Sumbersari bisa mengetahui, mengerti dan memahami tentang arti produk halal, kemudian mengetahui proses pengurusan sertifikasi halal terhadap produk usahanya, sekaligus bagaimana cara mendaftarkannya, sehingga mampu menaikkkan omset penjualan produknya.

Manfaat Kegiatan kegiatan pengabdian masyarakat ini antara lain : 
1. Memperat silaturahim antara Universitas dengan masyarakat melalui pendampingan kepada pelaku UMKM

2. Mengoptimalkan potensi penjualan UMKM dengan mengedukasi pentingnya label sertifikasi halal produk dan bagaimana mengurus label sertifikasi halal produk

3. Meningkatkan pemberdayaan masyarakat dengan memberikan bekal pengetahuan dn pemahaman dengan tetap mengikuti perkembangan jaman, khususnya teknologi yang berkaitan dengan sertifikasi halal produk, sehingga memberikan dampak terhadap penjualan produk UMKM (Yuwana, 2020)

\section{METODE}

Kegiatan ini dilaksanakan dengan sasaran pelaku UMKM di Kecamatan Sumbersari, Jember. Pelaku UMKM tersebut antara lain Toko Sima, yang terletak di Jalan Sumatra, kemudian FAFINA Outlet, yang terletak di Perumahan Sriwijaya dan WND, yang terletak di Jl. Letjen Suprapto Jember

Struktur pelaksana kegiatan dalam pengabdian masyarakat ini tersusun dari tim pelaksana terdiri dari 2 (dua) pengabdi dalam melakukan pendampingan literasi sertifikat halal produk pelaku UMKM, dengan tahapan kegiatan yang dilakukan, sebagai berikut :

Tabel 1. Tahapan Pelaksanaan Literasi Produk Halal

\begin{tabular}{|c|c|c|c|c|}
\hline No & Kegiatan & Metode & Output & Pelaksana \\
\hline 1 & $\begin{array}{l}\text { Memaparkan materi } \\
\text { Etika Bisnis Islam }\end{array}$ & $\begin{array}{l}\text { Ceramah dan } \\
\text { Diskusi }\end{array}$ & $\begin{array}{l}\text { Meningkatkan pemahaman } \\
\text { pelaku UMKM tentang etika } \\
\text { berbisnis yang Islami }\end{array}$ & Tim PKM \\
\hline 2 & $\begin{array}{l}\text { Pre test materi label dan } \\
\text { sertifikat halal }\end{array}$ & Kuesioner & $\begin{array}{l}\text { Gambaran pengetahuan pelaku } \\
\text { UMKM tentang teori halal }\end{array}$ & Tim PKM \\
\hline 3 & $\begin{array}{l}\text { Penjelasan tentang } \\
\text { prosedur dan tata cara } \\
\text { pengurusan sertifikat } \\
\text { halal produk }\end{array}$ & $\begin{array}{l}\text { Penyiapan } \\
\text { Dokumen }\end{array}$ & $\begin{array}{l}\text { Meningkatkan pengetahuan } \\
\text { pelaku UMKM tentang tahapan } \\
\text { pengurusan sertifikat halal dan } \\
\text { dokumen yang perlu disiapkan }\end{array}$ & Tim PKM \\
\hline 4 & $\begin{array}{l}\text { Penjelasan tentang } \\
\text { materi peran sertifikat } \\
\text { halal dalam pemasaran } \\
\text { produk UMKM, } \\
\text { utamanya untuk } \\
\text { meningkatkan penjualan }\end{array}$ & $\begin{array}{l}\text { Ceramah dan } \\
\text { Diskusi }\end{array}$ & $\begin{array}{l}\text { Meningkatnya pemahaman } \\
\text { pelaku UMKM tentang pentingnya } \\
\text { sertifikat halal dalam pemasaran } \\
\text { suatu produk, termasuk untuk } \\
\text { meningkatkan minat beli } \\
\text { konsumen serta meningkatkan } \\
\text { volume penjualan }\end{array}$ & Tim PKM \\
\hline 5 & $\begin{array}{l}\text { Post test materi label } \\
\text { dan sertifikat halal }\end{array}$ & Kuesioner & $\begin{array}{l}\text { Gambaran penguasaan pelaku } \\
\text { UMKM terkait materi label dan } \\
\text { sertifikat halal }\end{array}$ & Tim PKM \\
\hline 6 & $\begin{array}{l}\text { Pembuatan laporan } \\
\text { akhir pengabdian }\end{array}$ & $\begin{array}{l}\text { Kompilasi } \\
\text { seluruh bab, } \\
\text { pengolahan } \\
\text { data dan } \\
\text { penggandaan } \\
\text { laporan }\end{array}$ & Laporan Akhir & Tim PKM \\
\hline
\end{tabular}

Sumber : Data Diolah, 2021 
Metode yang di gunakan dalam kegiatan pengabdian ini adalah ceramah dengan teknik diskusi interaktif dengan melibatkan seluruh peserta. Metode pelatihan ceramah digunakan dalam penyampaian materi tentang pentingnya sertifikasi halal produk, dan mengaplikasikanya sehingga bermanfaat bagi penjualan produk itu sendiri. Untuk memberikan pemahaman lebih dalam terhadap materi literasi produk halal, semua peserta diberi kesempatan untuk berdiskusi dan tanya jawab. Narasumber juga memberikan contoh nyata dari penerapan sertifikasi halal pada beberapa UMKM di Jember.

Tahapan yang dilaksanakan dalam program kegiatan pengabdian ini adalah:

1. Tim pelaksana mengajukan ijin pengabdian kepada universitas, melalui LP2M

2. Tim pelaksana mengadakan penjadwalan kunjungan dengan pelaku UMKM untuk menyesuaikan waktu

3. Tim pelaksana datang pada beberapa UMKM di Kecamatan Sumbersari

4. Pelaku UMKM diberikan informasi mengenai produk halal dan sertifikasi halal produk

5. Pelaku UMKM diberikan informasi mengenai bagaimana mengurus sertifkasi halal produk

6. Pelaku UMKM diberikan pemahaman tentang manfaat pengurusan sertifikasi halal produk

7. Membuat laporan hasil kegiatan pengabdian

\section{HASIL DAN PEMBAHASAN}

Program kegiatann pengabdian kepada masyarakat ini dengan judul Literasi Produk Bersertifikasi Halal Dalam Rangka Meningkatkan Penjualan pada UMKM Kecamatan Sumbersari, Jember telah berjalan dengan baik. Kegiatan literasi ini diikuti oleh 3 (tiga) UMKM di Kecamatan Sumbersari, Jember. Kegiatan literasi produk halal ini berlangsung dari Agustus sampai dengan Oktober 2021. Kegiatan literasi ini terdiri dari 3 Materi yang disampaikan yaitu : Pemaparan Etika Bisnis Islam, Prosedur dan mekanisme pengurusan sertifikat halal terhadap produk serta pentingnya sertifikat halal dalam pemasaran produk UMKM, utamanya untuk meningkatkan penjualan (Alma, 2009). Pemateri terdiri dari 2 Dosen yang dijadikan narasumber, yang merupakan anggota tim dalam pengabdian .

Tabel 2. Kegiatan Pengabdian Kepada Masyarakat Oleh Tim Pelaksana

\begin{tabular}{|c|c|c|c|}
\hline No & Kegiatan & Pemateri & Output \\
\hline 1 & $\begin{array}{l}\text { Sosialisasi rencana kegiatan literasi } \\
\text { sertifikat produk halal }\end{array}$ & Tim PKM & $\begin{array}{l}\text { Sinkronisasi informasi dan } \\
\text { jadwal dari pelaku UMKM }\end{array}$ \\
\hline 2 & Penjelasan Etika Bisnis Islam & Tim PKM & $\begin{array}{l}\text { Penambahan pengetahuan } \\
\text { bisnis pelaku UMKM yang } \\
\text { sesuai dengan nilai-nilai islam }\end{array}$ \\
\hline 3 & $\begin{array}{l}\text { Penjelasan Sertifikat Halal dalam } \\
\text { perspektif islam dan perannya dalam } \\
\text { pemasaran produk }\end{array}$ & Tim PKM & $\begin{array}{l}\text { Pemahaman pelaku UMKM } \\
\text { tentang sertifikat halal dalam } \\
\text { perspektif agama dan } \\
\text { pemasaran }\end{array}$ \\
\hline 4 & $\begin{array}{l}\text { Pre test dan Pos Test Sertifikat Halal } \\
\text { produk }\end{array}$ & Tim PKM & $\begin{array}{l}\text { Gambaran sikap dan perilaku } \\
\text { pelaku UMKM sebelum dan }\end{array}$ \\
\hline
\end{tabular}




\begin{tabular}{llll}
\hline & & & $\begin{array}{l}\text { sesudah mendapatkan } \\
\text { pengetahuan dari narasumber } \\
\end{array}$ \\
& & & pengabdian \\
\hline 5 & Penjelasan tentang prosedur dan tata & Tim PKM & Koordinasi dengan pelaku \\
& cara pengurusan sertifikat halal & & UMKM tentang berbagai \\
& produk & & dokumen yang perlu disiapkan \\
& & & untuk pengurusan sertifikat \\
& & & halal. \\
\hline 6 & Pembuatan Laporan Akhir & Tim PKM & Laporan Akhir \\
\hline 7 & Pembuatan Artikel Literasi sertifikat & Tim PKM & Publikasi Artikel di Jurnal \\
& halal produk UMKM & & Nasional \\
\hline
\end{tabular}

Sumber : Data Diolah, 2021

Dalam kegiatan pendampingan literasi pengurusan sertifikat halal, Tim Pengabdian Kepada Masyarakat (PKM) melakukan beberapa kegiatan dengan tujuan untuk memberikan pemahaman secara teori tenang pentingnya bisnis menurut tatanan nilai-nilai islam. Dalam kegiatan usahanya, diharapkan pelaku UMKM memiliki etika bisnis yang sesuai dengan tuntunan nilai-nilai islam. Hal ini didasarkan pada kenyataan dimana saat usaha UMKM berkembang dan permintaan terhadap produk terus meningkat akan memberikan peluang munculnya perilaku yang bertentangan dengan nilai-nilai Islam, misalnya dalam proses pembuatan terjadi penyalahgunaan bahan dengan harapan menuai keuntungan yang lebih besar. Selain itu, perkembangan usaha akan memunculkan sikap ingin untung sendiri sehingga menimbulkan persaingan yang tidak sehat diantara pelaku UMKM. Oleh karena itu untuk meminimalisir sikap-sikap yang kurang baik, tim PKM memberikan materi tentang bagaimana Islam mengatur bisnis yang saling menguntungkan dan saling membesarkan tanpa menjatuhkan.

Pemaparan materi disampaikan selama satu jam, selanjutnya dengan sesi tanya jawab. Dalam kegiatan diskusi, ada sejumlah pertanyaan yang didiskusikan tentang bagaiman agar bisnis tetap konsisten dan bagaimana melakukan koordinasi kegiatan dengan pelaku UMKM yang lain agar usaha mereka terus berjalan lancar dan tidak ada kelompok yang tertinggal. Kegiatan pendampingan literasi di tahap pertama diakhiri dengan sebuah kesimpulan bahwa diantara pelaku UMKM bukanlah pesaing tetapi saudara yang harus saling mendukung. Jika ada pesanan yang tidak dapat ditangani, maka kerjasama antar pelaku UMKM ini adalah jawabannya.

Setelah pelatihan etika bisnis, maka pelatihan yang kedua adalah tentang Sertifikat Halal dalam perspektif islam dan perannya dalam pemasaran produk. Sebelum dilakukan pemaparan materi, maka tahap pertama membagikan kuesioner kepada pelaku UMKM dengan tujuan untuk menangkap sejauh mana pengetahuan pelaku UMKM tentang sertifikat produk halal. Pengisian kuesioner berlangsung 10 menit yang dilanjutkan dengan pemaparan materi oleh narasumber tentang label dan sertifikasi halal. Narasumber juga menjelaskan pentingnya pengurusan sertifikasi halal dan memberikan contoh pelaku usaha yang sudah menikmati efek 
pengurusan ini. Pemaparan materi berlangsung 90 menit yang diakhiri dengan diskusi. Diskusi sangat menarik karena ada beberapa pertanyaan dari pelaku UMKM yang menjadi subyek penelitian. Pertemuan diakhiri dengan pengisian kuesioner posttest tentang sertifikasi halal. Setelah kuesioner pretest dan posttestdiolah, maka hasilnya adalah sebagai berikut :

1. Apakah pelaku UMKM memiliki informasi yang cukup tentang sertifikasi dan label halal? Pertanyaan yang pertama diajukan berkaitan dengan informasi yang dimiliki oleh pelaku UMKM Sumbersari mengenai sertifikasi dan logo halal. Dari hasil pengolahan data terlihat sebelum ada pemaparan 2 pelaku UMKM Sumbersari mengaku sudah memiliki informasi tentang label dan sertifikat halal. Hal ini merupakan indikasi bahwa informasi tentang label dan sertifikasi halal yang dimiliki oleh pelaku UMKM Sumbersari belum merata. Padahal jaminan keamanan suatu produk terutama dari sisi syar'i instrumennya adalah label halal. Jika pelaku UMKM tidak mengetahui tentang pengetahuan label halal maka akan terjatuh pada kegiatan mengkonsumsi suatu barang yang belum ada kejelasan hukumnya. Diketahui bahwa Alloh telah berfirman secara jelas dalam beberapa surat didalam Al Quran, diantaranya surat Al Baqarah surat Al Maidah, dimana manusia harus makan dan minum yang halal lagi baik. Oleh karena itu pengetahuan tenang label halal harus menjadi pengetahuan umum yang harus dimiliki oleh siapapun termasuk pelaku UMKM sehingga dalam berkonsumsi akan lebih bersikap hati-hati supaya tidak terjebak dalam konsumsi barang-barang yang diharamkan. Setelah diberikan materi tentang label dan sertifikasi halal, dapat terlihat bahwa ada beberapa perubahan sikap dan perilaku pelaku UMKM dalam memahami label halal dari suatu produk. Setelah diberikan materi, pelaku UMKM mempersepsikan dengan informasi yang banyak tentang label dan sertifikasi halal. Jika dalam pretest ada 1 pelaku UMKM yang tidak memiliki informasi banyak tentang label halal, maka setelah mengikuti pelatihan dan mendengarkan pemaparan, tiga pelaku UMKM semuanya menjadi paham. Artinya pelaku UMKM Sumbersari benar-benar menyimak pemaparan dari narasumber dalam acara pendampingan literasi tersebut.

2. Apakah pelaku UMKM pernah melihat suatu kemasan prodauk dengan logo halal? Hasil pengolahan data, baik sebelum maupun sesudah pembekalan materi label halal, tiga pelaku UMKM Sumbersari yang menjadi subyek sasaran sudah pernah melihat logo halal di kemasan suatu produk. Artinya pelaku UMKM sedikit banyak telah memiliki perhatian untuk memperhatikan elemen-elemen dari suatu kemasan. Selain nama merek, ingredient produk, tanggal kadaluwarsa maka label halal merupakan salah satu elemen yang harus muncul dalam produk makanan maupun minuman. Adanya label halal menunjukkan bahwa produk makanan atau minuman sudah melewati satu tahap pengujian kehalalan baik dari bahan-bahan, proses maupun penyimpanannya sudah sesuai ketentuan yang di fatwakan MUI (Nasrullah, 2015). Artinya konsumen sudah aman memakan dan meminum produk yang dibelinya. Pengakuan pelaku UMKM, selama ini tidak begitu memperhatikan elemen-elemen daari kemasan selalin warna kemasan dan nama produk. Melihat fakta tersebut maka menjadi penting untuk meningkatkan pengetahuan pelaku UMKM tentang elemen-elemen penting yang harus diperhatikan 
dalam sebuah kemasan. Pengetahuan tersebut akan menumbuhkan kesadaran pelaku UMKM tentang berbagai informasi yang harus dikeahui dari suatu produk, sehingga konsumen dari para pelaku UMKM akan terlindung dari hal-hal yang tidak diinginkan.

3. Apakah pelaku UMKM pernah membaca logo halal di kemasan?

Pelaku UMKM mengaku mengetahui label halal selain dari melihat logo tersebut di kemasan tetapi juga dari membaca. Sebagian besar pelaku UMKM Sumbersari mengaku pernah membaca logo halal dari berbagai sumber, seperti majalah dan koran, yang tidak sengaja mereka lihat dan membahas tentang label halal. Namun demikian menurut pengakuan pelaku UMKM, mereka hanya mengetahui sekilas saja, tidak banyak informasi yang dapat mereka tangkap. Bagi mereka, label halal bukanlah hal yang utama dibandingkan dengan keutamaannya untuk menjual demi mencari nafkah menghidupi keluarga.

4. Apakah pelaku UMKM memahami maksud dari logo halal?

Pertanyaan lebih lanjut tentang pengetahuan tentang maksud label halal, sebagian besar pelaku UMKM mengetahui maksud dari label tersebut. Namun pengetahuan tenang apa maksud dari label halal, tidak banyak yang diketahui oleh pelaku UMKM. Mereka hanya mengetahui bahwa maksud dari logo halal adalah makanan dan minuman aman untuk dimakan atau diminum. Label halal merupakan sebuah jaminan dari MUI bahwa produk makanan maupun minuman itu aman untuk dikonsumsi. Proses untuk mendapatkan label halal merupakan suatu proses yang cukup panjang dan harus dilalui oleh seorang pelaku usaha supaya mendapatkan sertifikat halal.

5. Apakah pelaku UMKM mengetahui logo resmi yang dikeluarkan oleh MUI?

Logo merupakan lambang atau simbol khusus yang mewakili suatu perusahaan atau organisasi. Logo bisa berupa nama, lambang atau elemen grafis lain yang ditampilkan secara visual. Sebuah logo diciptakan sebagai identitas agar mempunyai keunikan dan menjadi pembeda dengan perusahaan kompetitor. Logo bisa diibaratkan wajah. Setiap orang dikenal karena wajahnya. Begitupun dengan perusahaan atau instansi akan terekam dalam benak penggunanya dari logo. Logo juga merupakan sebuah visi penyampaian citra positif melalui sebuah visual tampilan sederhana dalam bentuk simbol. Terkait dengan logo halal yang diterbitkan resmi oleh MUI, pelaku UMKM pada umumnya mengaku mengetahuinya. Mereka mengungkapkan logo label halal MUI berbentuk bulat dimana di tengah-tengah lingkaran ada tulisan huruf arab halal dengan latar hijau. Diantara lingkaran ada tulisan Majelis Ulama Indonesia. Berikut logo resmi yang dikeluarkan MUI :

6. Apakah pelaku UMKM mengetahui masa berlakunya label halal?

Pengetahuan pelaku UMKM tentang masa berlakunya sertifikat halal beragam. Sebelum dilakukan literasi pemaparan label halal, hanya 1 dari 3 subyek penelitian, yang mengaku mengetahui masa berlakunya logo halal tersebut. pasca pelatihan, ternyata pengakuan pelaku UMKM Sumberari meningkat. Semua responden pengabdian yang berasal dari pelaku UMKM Sumbersari sangat mengetahui tentang masa kadaluwarsa sertifikat halal MUI. Mengetahui bentuk logo ini sangat penting mengingat saat ini logo MUI banyak 
disalahgunakan. Banyak beredar di masyarakat stiker LOGO MUI, yang dapat digunakan oleh orang-orang yang tidak bertanggungjawab. Beredarnya logo halal yang di luar produsen MUI tersebut akan sangat meresahkan, karena proses pengujian dan validasi dari MUI tidak pernah dilakukan.

Masa berlakunya sertifikasi halal yang diterbitkan oleh Majelis Ulama Indonesia, yaitu:

a. Sertifikasi halal hanya berlaku selama dua tahun, sedangkan untuk daging yang diekspor, surat keterangan diberikan dalam setiap pengapalan

b. Tiga bulan sebelum berakhir masa berlakunya sertifikat LPPOM, MUI akan mengirimkan surat pemberitahuan kepada produsen yang bersangkutan untuk segera mendaftar kembali

Pertama kali sertifikat halal berlaku selama 2 tahun. Namun dengan adanya Ketetapan Majelis Ulama Indonesia (MUI) berdasarkan Nomor Kep-49/DHN-MUI/V/2021, mengalami perubahan masa berlakunya menjadi 4 tahun. 'Sertifikat halal memiliki masa berlaku selama 4(empat) tahun sejak diterbitkan oleh Badan Penyelenggara Jaminan Produk Halal (BPJPH), terkecuali jika ada perubahan komposisi dari bahannya.

7. Apakah pelaku UMKM mengetahui fungsi label halal yang berhubungan dengan peningkatan volume penjualan?

Hasil pengolahan data terungkap bahwa sebelumnya pelaku UMKM banyak yang kurang sadar akan fungsi dari label halal. Pemahaman terhadap fungsi label halal ini semakin meningkat setelah pelaku UMKM mengikuti pelatihan literasi sertifikat produk halal. Fungsi dari label halal yaitu :

a. Menguntungkan bagi konsumen dengan memberikan perlindungan dan kepastian hukum

b. Menguntungkan bagi produsen dengan peningkatan daya saing serta omset produksi dalam penjualan

c. Menguntungkan bagi pemerintah dengan mendapatkan tambahan pemasukan untuk kas negara

Dengan adanya fungsi label halal ini akan memperkuat citra produk UMKM kepada masyarakat, secara langsung maupun tidak langsung dapat mempengaruhi keinginan dan keputusan pembelian konsumen. Semakin banyak masyarakat yang yakin akan produk UMKM, maka akan semakin tinggi pula minat beli, yang nantinya akan berujung pada meningkatnya volume penjualan produk UMKM tersebut.

Pemaparan selanjutnya adalah Penjelasan tentang prosedur dan tata cara pengurusan sertifikat halal produk. Narasumber menjelaskan tahapan dan dokumen yang perlu dipersiapkan sebagai persyaratan pengurusan sertifikasi produk halal.

Tahapan Proses Pengurusan Sertifikasi Halal : Ada 3 pihak yang dilibatkan dalam proses sertifikasi halal, yaitu BPJPH, LPPOM MUI merupakan lembaga pemeriksa halal (LPH), dan MUI. BPJPH yang melaksanakan penyelenggaraan jaminan produk halal. LPPOM MUI melakukan pemeriksaan mengenai kecukupan dokumen, penjadwalan audit, pelaksanaan audit, pelaksanaan rapat auditor, penerbitan audit memorandum, penyampaian berita acara 
hasil audit pada rapat Komisi Fatwa MUI. MUI menetapkan kehalalan produk berdasarkan hasil audit dan menerbitkan Ketetapan Halal MUI melalui Komisi Fatwa.

\section{SIMPULAN}

Setelah melakukan pendampingan literasi sertifikasi produk halal pada pelaku UMKM Kecamatan Sumbersari, Jember, maka diperoleh beberapa kesimpulan sebagai berikut :

1. Dilihat dari sisi pengetahuan pelaku UMKM terkait label dan produk halal, ada perbedaan sebelum dan sesudah diadakan pendampingan literasi, dimana menunjukkan adanya peningkatan pemahaman pelaku UMKM setelah diberikan pelatihan literasi sertifikasi produk halal

2. Pelaku UMKM dapat mengerti dan memahami tahapan proses pengurusan produk halal, apa saja dokumen yang diperlukan dan mengetahui instansi yang menjadi arah tujuan pengurusan

3. Pelaku UMKM dapat memahami arti penting pengurusan sertifikat produk halal, dan mengerti pengaruh pentingnya terhadap volume penjualan produk UMKM

\section{UCAPAN TERIMA KASIH}

Penulis mengucapkan terimakasih kepada banyak pihak terkait yang membantu terlaksananya kegiatan ini. Ucapan Terimakasih kepada UIN KHAS Jember melalui LP2M yang memfasilitasi program pengabdian ini. Terimakasih kepada dinas terkait di Kabupaten Jember yang mengurusi sertifikasi halal. Terimakasih kepada para pelaku UMKM di Kecamatan Sumbersari, Jember, khususnya pelaku usaha yang dijadikan sebagai narasumber dalam program pengabdian masyarakat ini. Semoga program pengabdian ini memberikan kontribusi nyata bagi perkembangan UMKM dan kemajuan perekonomian Kabupaten Jember.

\section{REFERENSI}

Al Farisi, M. S. (2020). Preferensi MASYARAKAT TERHADAP PEMBELIAN PRODUK MAKANAN HALAL DI DUSUN MLANGI YOGYAKARTA: MASYARAKAT TERHADAP PEMBELIAN PRODUK MAKANAN HALAL DI DUSUN MLANGI YOGYAKARTA. Jurnal Manajemen Bisnis Dan Keuangan, 1(2), 60-75.

Alma, H. B. (2009). Manajemen pemasaran dan pemasaran jasa.

Farhan, A. (2018). Pelaksanaan Sertifikasi Halal Lppom Mui Terhadap Produk Usaha Mikro, Kecil Dan Menengah (UMKM)(Studi LPPOM MUI Provinsi Bengkulu), Manhaj: Jurnal Penelitian dan Pengabdian Masyarakat Vo. 3 (1). DOI: Http://Dx. Doi. Org/10.29300/Mjppm. V3i1, 2340, g1949.

Nasrullah, M. (2015). Islamic Branding, Religiusitas dan keputusan konsumen terhadap produk. Jurnal Hukum Islam, 13(2), 79-87.

Salehudin, I., \& Mukhlish, B. M. (2012). Pemasaran Halal: Konsep, Implikasi dan Temuan Di Lapangan (Halal Marketing: Concept, Implication and Field Finding). Dulu Mendengar Sekarang Bicara: Kumpulan Tulisan Ekonom Muda FEUI, 293-305.

Yuwana, S. I. P. (2020). Coronanomics: Strategi Revitalisasi UMKM Menggunakan Teknologi Digital di Tengah Pandemi Covid-19. Journal of Technopreneurship on Economics and Business Review, 2(1), 47-59. 